\title{
Development of water resources in Koya city, Iraq
}

\author{
N. A. Al-Ansari ${ }^{1}$, S. Zakaria ${ }^{1}$, Y. T. Mustafa ${ }^{2}$, P. S. Ahmed ${ }^{3}$, \\ B. D. Ghafour ${ }^{3} \&$ S. Knutsson ${ }^{1}$ \\ ${ }^{1}$ Department of Civil, Environmental and \\ Natural Resources Engineering, Lulea University, Sweden \\ ${ }^{2}$ College of Engineering, Zakho University, Iraq \\ ${ }^{3}$ College of Engineering, Koya University, Iraq
}

\begin{abstract}
Iraq is facing a water shortage problem, which is becoming more severe with time. Rain water harvesting (RWH) can help to minimize the water shortage problem. Seven years of rainfall records were used to find out the quantity of water that can be harvested using a watershed modeling system (WMS).

Koya city is located in the northern part of Iraq. The population of the city is about 39,484.The application of the WMS model for rainfall records of seven years (2002/3 to 2010/11) showed that 275.51 million cubic meters of water can be harvested. This implies that the annual average of rain harvested water is 39.4 million cubic meters and the allocation per capita to be 997 cubic meters per year. This amount of water can greatly help the development of industry and agriculture in the city.

Keywords: macro rainwater harvesting, Koysinjaq, Kurdistan region, Iraq.
\end{abstract}

\section{Introduction}

The Middle East is considered as a semi-arid area where the average annual rainfall does not exceed 166mm [1]. In view of this fact scarcity of water resources in this region represent an extremely important factor in the stability and economic development within the region [1, 2]. Future predictions suggest more shortages [3-5] and depletion of groundwater resources [6, 7]. Tigris and Euphrates Rivers will be completely dry by 2040 [8]. Due to the presence of the Rivers Tigris and Euphrates, Iraq was an exception till the 1970s [9-11]. 
Construction of dams on the Tigris and Euphrates and their tributaries outside the border of Iraq, the effect of global climate change and mismanagement of water resources are the main factors in the water shortage problems in Iraq [11]. Restoring the marshes $[12,13]$ and the growing demand for water in Turkey and Syria will lead to dry the Tigris and Euphrates Rivers in 2040 [8]. Furthermore, the supply will be 43 and 17.61 BCM in 2015 and 2025 respectively while current demand is estimated between 66.8 to 77 BCM. These suggest that the Iraqi government need to take quick, prudent and firm action as a high priority. One of the solutions is the use of Water Harvesting techniques [11].

To overcome these problems in Iraq, there is a great need for prudent management of water resources and the adaptation of non- conventional techniques to augment water resources $[9,11]$. One of the non-conventional techniques that can be used to overcome water shortage is rain water harvesting $(\mathrm{RWH})$. It is one of the oldest-most recent techniques that collect water from natural catchment areas to augment available water for certain area. Humans have used RWH about 9000 years ago as a traditional technique [14, 15] in order to supply drinking water for people and livestock as well as the agricultural purpose, as far as there is a limited amount of available water. In recent decades, and due to water scarcity, different researchers at different part of the world focused on RWH. The goal is to establish a new water source. There are several definitions for RWH but the shortest and most comprehensive definition is the collection of runoff for its productive use [16]. RWH systems have proven to be an effective technique in the arid and semi-arid region to achieve new water source that can be used for several purposes [15]. The most important factors that affect practicing water harvesting are the intensity and distribution of rainfall, runoff properties of the catchment area, soil water storage, reservoir's capacity, agricultural crops, available technologies and socio-economic conditions [17].

The average annual rainfall in Iraq as stated by various authors is ranging from 154 to $216 \mathrm{~mm} /$ year $[18,19]$. The Encyclopaedia of the Earth and FAO $[20,21]$ but varies where it reaches $150 \mathrm{~mm}$ within the western desert, more than $1000 \mathrm{~mm}$ within the mountains to the north to about $200 \mathrm{~mm}$ at the eastern part of the country (Figure 1). It should be mentioned, however, that despite the local climatic differences, all the regions have similar overall climatic features. This is due to the fact that Iraq as a whole is affected by its geographic position. When rainfall is used as a base to classify the climate, two seasons can be noticed: Dry season starting in April to September and Wet season starting in October to May. It can be stated that October represents the transition period from dry to wet seasons while May representing the transition from humid to dry season.

From the rainfall distribution map, it is evident that RWH can be applied successfully in the northern parts of Iraq. For this reason the Ministry of Agriculture and Water Resources in Kurdistan Region is executing some dams in the region [22].

The aim of this research is to test the Macro RWH in Koysinjaq (Koya) District, Kurdistan region of Iraq to discover the capability of the region for 


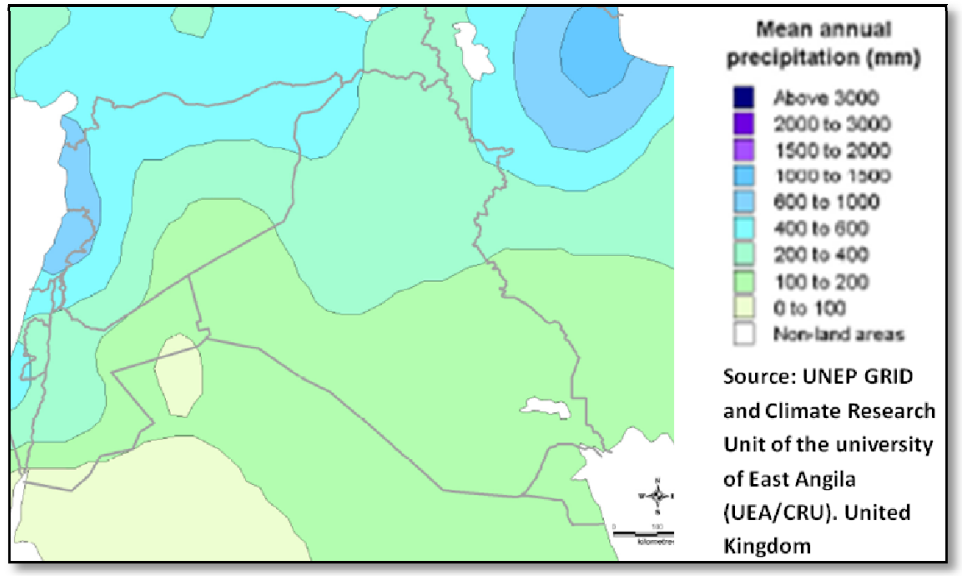

Figure 1: Rainfall map of Iraq (http://reliefweb.int/map/iraq/iraq-meanannual-precipitation-mm).

rainwater harvesting in order to save significant runoff water for different purposes then to contribute solving the problem of water shortage of Iraq.

\section{Study area}

Koya (Koysinjaq) district (Figure 2) is located within Erbil Governorate in the northeast. According to Iraqi statistics of 1987, the Koysinjaq population is about 39,484 people. Koysinjaq (Koya) geographically is a mountainous area with different uphill at the north, while at the south and southwest, fertility plain extends to the border of Erbil with Kirkuk city, which represents the historical alluvial plain of the Tigris River. The intensive farming of wheat and barley are distributed in the plain of Erbil south of Koysinjaq (Koya) districts. Accordingly, the average depth of the soil increases from the north to the south to reach up to 1.3 meters [23]. Buringh [24] described the soil of study area as a brown soil medium and shallow phase over Bakhtiary gravel. People in Koya depend on rain and groundwater for agricultural processes.

\section{Methodology}

To apply RWH technique for Koya, a digital Elevation Model (DEM) was used with Global Mapper model in order to find suitable locations for the harvested dams. The locations were highly controlled by the local topography of the area. It is to satisfy, first crosscut with the final main runoff trajectories of the catchment area. Second minimum dams cross section that lead to minimum ratio of reservoir's surface area to its storage volume in order to minimize the dams constructions cost as well as to minimize the losses water by evaporation processes from reservoir's surface area were used. The second stage was to apply Watershed modeling system (WMS) with Koya's DEM, its land use, soil type 
and rainfall data, firstly, to figure out the selected basins and their properties then to estimate the runoff volumes based on Soil Conservation Services-Curve Number (SCS-CN) method. Full details of the procedure and calibration of the model that was used are reported by Al-Ansari et al. [25].

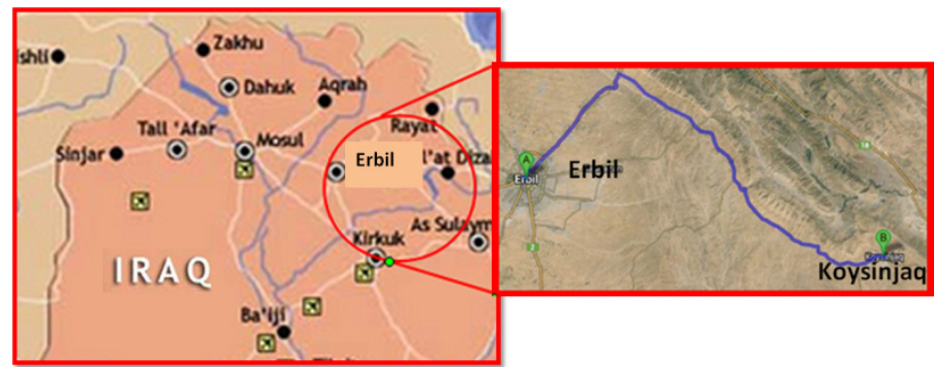

Figure 2: Location of Koysinjaq area according to the Erbil city in the Kurdistan region of Iraq, (source: flickr.com and Google maps).

The data required were first, the rainfall records for 7 years (2002-2011) were studied, two seasons (2007-2008 and 2008-2009) were neglected due to missing data. Secondly, the land use/land cover (LULC) map provides information about the types of features found on the earth's surface and the human activity that is associated with them (land use). It is an important indicator for calculating the curve number for the suitable sites for catchment sites for rainwater harvesting. In this study, the LULC was derived from satellite imagery, Landsat 8, that provided by the National Aeronautics and Space Administration (NASA). The image was acquired on June 15, 2013 which has 11 bands with a $30 \mathrm{~m}$ spatial resolution. It is registered using the Universal Transverse Mercator (UTM) Projection Zone 38 North with a World Geodetic System (WGS) 84 datum. Moreover, the image is atmospherically corrected using the darkest pixel method which is also known as the histogram minimum method (Figure 3). Using these data and the elevation model of the area, 4 basins were selected that satisfy the conditions set by the model and to achieve minimum cost of the water harvesting dams (Figure 3). Then the above data were used in the WMS model.

\section{Results and discussion}

WMS is an efficient tool to estimate runoff for a specific catchment area. It has the ability to provide the properties of the selected basins, (area, length, elevation and slope. Furthermore, WMS can support the calculation to estimate the properties of the reservoirs and dams. It should be mentioned that, the predominant factor was the short length which gives a minimum cost when constructing these dams. For this research, dams of $6 \mathrm{~m}$ height were selected, and according to the selected height, the length of the dams, total capacity of the reservoirs as well as their surface area was estimated (Table 1). 


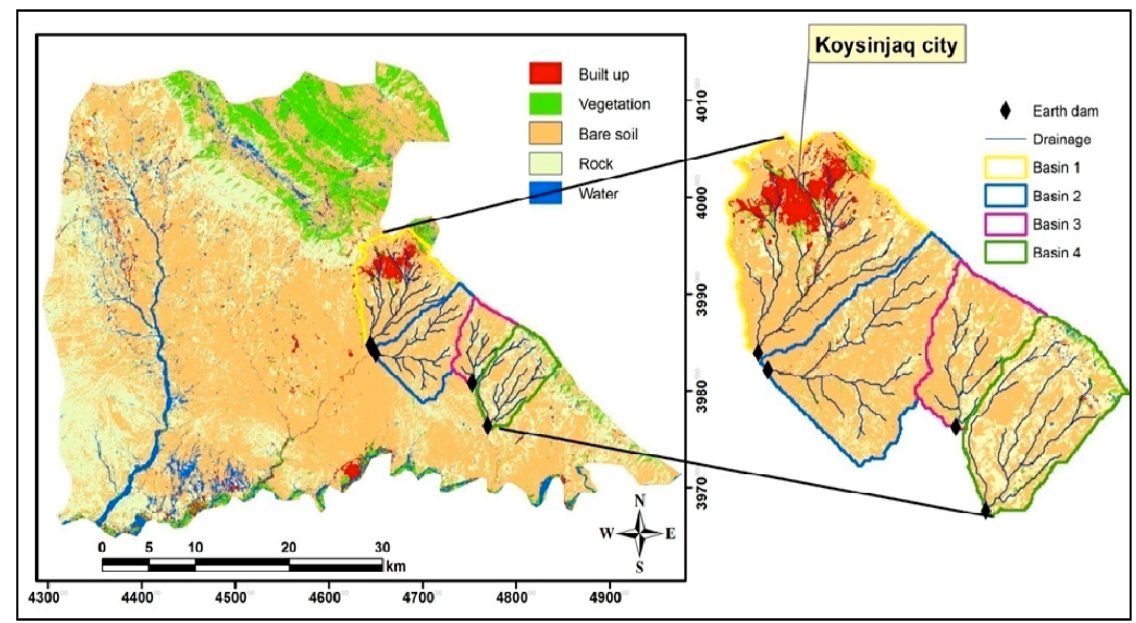

Figure 3: $\quad$ LULC map of the selected four basins area.

Table 1: $\quad$ Properties of the reservoirs and dams at Koya.

\begin{tabular}{ccccc}
\hline Reservoir & $\begin{array}{c}\text { Max. surface } \\
\text { Area }\left(\mathbf{k m}^{\mathbf{2}}\right)\end{array}$ & $\begin{array}{c}\text { Max. storage } \\
\left.\mathbf{( * \mathbf { 1 0 }}^{\mathbf{6}} \mathbf{~ m}^{\mathbf{3}}\right)\end{array}$ & $\begin{array}{c}\text { Dam } \\
\text { height } \\
\mathbf{( m )}\end{array}$ & $\begin{array}{c}\text { Dam } \\
\text { length } \\
\mathbf{( m )}\end{array}$ \\
\hline 1B & 0.401 & 0.378 & 6.0 & 110.0 \\
2B & 0.633 & 0.685 & 6.0 & 233.3 \\
3B & 0.098 & 0.083 & 6.0 & 092.0 \\
4B & 0.330 & 0.363 & 6.0 & 123.6 \\
\hline
\end{tabular}

The harvested runoff from the four individual basins was calculated using WMS and is shown in Figure 4 and Table 2.

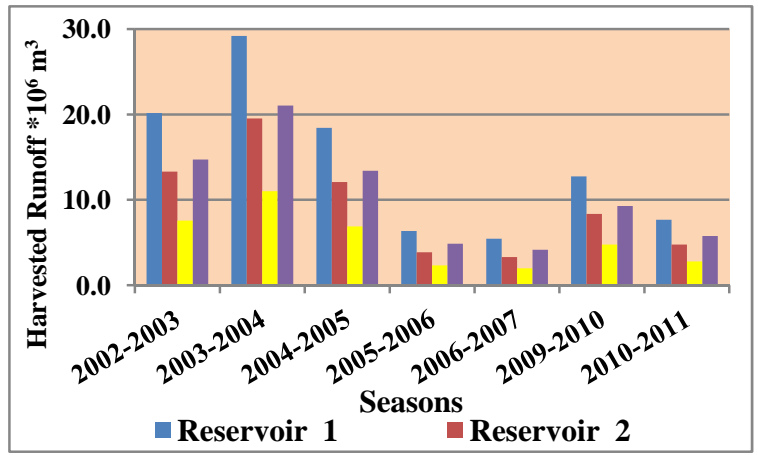

Figure 4: Harvested runoff volumes in the individual four reservoirs for the study period (2002-2011). 
Table 2: $\quad$ Quantities of rainwater that can be harvested in Koya.

\begin{tabular}{cccccc}
\hline \multirow{2}{*}{ Year } & \multicolumn{5}{c}{ Volume of Harvested Water $\left({ }^{*} 10^{6} \mathrm{~m}^{3}\right)$} \\
\cline { 2 - 6 } & Basin 1 & Basin 2 & Basin 3 & Basin 4 & Total \\
\hline $2002-3$ & 20.17 & 13.31 & 7.57 & 14.71 & 55.75 \\
$2003-4$ & 29.19 & 19.52 & 11.01 & 21.04 & 80.77 \\
$2004-5$ & 18.42 & 12.08 & 6.88 & 13.40 & 50.78 \\
$2005-6$ & 6.34 & 3.84 & 2.31 & 4.86 & 17.35 \\
$2006-7$ & 5.44 & 3.29 & 1.97 & 4.14 & 14.83 \\
$2009-10$ & 12.75 & 8.35 & 4.75 & 9.26 & 35.11 \\
$2010-11$ & 7.66 & 4.75 & 2.78 & 5.75 & 20.93 \\
\hline Overall total & & & & & 275.51
\end{tabular}

It indicates that an average of 39.4 million cubic meters can be harvested annually. This gives about 997 cubic meters per capita to the population of Koya which is about 6 times the international average allocation in various countries and in Iraq [26]. This amount of water can irrigate hundreds of square kilometres in the vicinity of Koya. Table 1 shows the properties of the 4 selected dams in the Koya area.

\section{Conclusions}

Iraq in general is facing water shortage problem, and it is getting more severe with time. To overcome this problem, it is believed that RWH can be one of the solutions especially in the northern parts of Iraq where the annual rainfall is higher than it is in the middle and southern parts. Rainfall records of Koya city during the period 2002/3 to 2010/11 indicated that an average of 39.4 million cubic meters can be harvested annually. This amount when distributed gives about 997 cubic meters per capita to the population of Koya. Furthermore, large areas on the plains within the vicinity of Koya can be cultivated. In summary, RWH can help tremendously in Koya city development.

\section{Acknowledgements}

Thanks to Mrs. Semia Ben Ali Saadaoui of UNESCO-Iraq and Professor Fuad Khoshnaw, Dean of the College of Engineering, Koya University for their encouragement and support. The research presented has been financially supported by Luleå University of Technology, Sweden and by the "Swedish 
Hydropower Centre - SVC” established by the Swedish Energy Agency, Elforsk and Svenska Kraftnät together with Luleå University of Technology, The Royal Institute of Technology, Chalmers University of Technology and Uppsala University. Their support is highly appreciated.

\section{References}

[1] Al-Ansari, N.A., Water Resources in the Arab countries: problems and possible solutions, Water: a looming crisis”, Intern. Conf. on World Water Resources at the beginning of the 21st century, UNESCO, Paris, 3-6 June 1998.

[2] Naff, T., Conflict and water use in the Middle East, in Roger, R. and Lydon, P. (Ed.), Water in the Arab Word: Perspectives and Prognoses, Harvard University, 253-284, 1993.

[3] Bazzaz, F., Global climatic changes and its consequences for water availability in the Arab World, in Roger, R. and Lydon, P. (Ed.), Water in the Arab Word: Perspectives and Prognoses, Harvard University, 243252, 1993.

[4] Al-Ansari, N.A., Salameh, E. and Al-Omari, I., Analysis of Rainfall in the Badia Region, Jordan, Al-Bayt University Research paper No.1, 66p, 1999.

[5] Hamdy, A., Water Crisis and Food Security in the Arab World: The Future Challenges, accessed on 23 August 2013. http://gwpmed.org/files/IWRMLibya/Atef\%20Hamdy\%20AWC.pdf

[6] Chenoweth, J., Hadjinicolaou, P., Bruggeman, A., Lelieveld, J., Levin, Z., Lange, M., Xoplaki, E. and Hadjikakoul, M., Impact of climate change on the water resources of the eastern Mediterranean and Middle East region: Modeled 21st century changes and implications, J. Water Resources Res., V. 47, W06506, 1-18, 2011.

[7] Voss K., Famiglietti, J., Lo, M., de Linage, C., Rodell, M. and Swenson, S., Groundwater depletion in the Middle East from GRACE with implications for transboundary water management in the Tigris-EuphratesWestern Iran region, Water Resources Research, V.49, 904-914, 2013.

[8] UN, Water Resources Management White Paper, United Nations Assistance Mission for Iraq, United Nations Country Team in Iraq, 20 p, 2010. http://iq.one.un.org/documents/100/white\%20paper-eng_Small.pdf

[9] Al-Ansari, N.A. and Knutsson, S., Toward Prudent management of Water Resources in Iraq, J. Advanced Science and Engineering Research, V. 1, 53-67, 2011.

[10] Al-Ansari, N.A., Alroubai, A. and, Knutsson, Bathymetry and Sediment survey for two old water harvesting schemes, Jordan, J. Earth Science and Geotechnical Engineering, V. 2, 2, 13-23, 2012.

[11] Al-Ansari, N.A., Management of Water Resources in Iraq: Perspectives and Prognoses, J. Engineering, V.5, 8, 667-684, 2013.

[12] UN, Managing Change in the Marshlands: Iraq's Critical Challenge, UN white paper, Report of the UN, 2011. 
[13] Al-Ansari, N.A., Knutsson, S. and Ali, A., Restoring the Garden of Eden, Iraq, J. Earth Science and Geotechnical Engineering, V. 2, No.1, 5388, 2012.

[14] Al-Ansari, N.A., Al-Hanbaly, M. and Knutsson, S., Hydrology of the most ancient water harvesting schemes, J. Earth Science and Geotechnical Engineering, V 3,1, 15-25, 2013.

[15] Prinz, D., Water Harvesting: Past and Future. In: Pereira, L. S. (ed.), Sustainability of Irrigated Agriculture. Proceedings, NATO Advanced Research Workshop, Vimeiro, 21-26.03, Balkema, Rotterdam, 135144, 1996.

[16] Siegert, K., 1994, Introduction to Water Harvesting. Some Basic Principles for Planning, Design and Monitoring. In: FAO, Water Harvesting For Improved Agricultural Production. Expert Consultation, Cairo, Egypt 21-25 Nov. 1994, p. 9-23, FAO, Rome, 1994. http://www.fao.org/docrep/u3160e/u3160e03.htm \#1.2 definitions and classification.

[17] Tauer, W. and Prinz, D., Runoff Irrigation in the Sahel Region: Appropriateness and Essential Framework Conditions. In: Proceedings, Intern. Conference on Advances in Planning, Design and Management of Irrigation Systems as Related to Sustainable Land Use, Leuven, Belgium, 14-17 Sept, 945-953, 1992.

[18] Aquastat (FAO's Information System on Water and Agriculture), Iraq, country profile, 2008. http://www.fao.org/nr/water/aquastat/countries _regions/IRQ/index.stm

[19] Al-Ansari, N. A., Assaid, H. I. and. Salim, V. N, 1981, Water Resources in Iraq, Journal of the Geological Society, Vol. 15, pp. 35-42,1981.

[20] The Encyclopedia of the Earth, 2008, Water profile of Iraq. http://www.eoearth.org/view/article/156951/

[21] FAO, Water profile of Iraq, 2008. http://www.eoearth.org/view /article/51cbef2d7896bb431f69ceb3/

[22] Ministry of Planning, Regional Development Strategy for Kurdistan Region 2013-2017, Ministry of Planning, July/2012. http://www.mopkrg.org/resources/Strategic\%20Plan/PDF/Regional\%20Development\%20S trategy\%20for\%20Kurdistan\%20Region\%202013-2017.pdf

[23] Kahraman, Layla M., Geographical analysis of the characteristics of soils and the problems of the province of Arbil and scalability land productivity, Erbil, 2004.

[24] Buringh, P., Soils and Soil Conditions, H. Veenman \& Zonen N. V., Netherlands, 1960.

[25] Al-Ansari, N.A., Ezz-Aldeen, M., Knutsson, S. and Zakaria, S., Water harvesting and reservoir optimization in selected areas of south Sinjar Mountain, Iraq, Accepted for publication in ASCE J. Hydrologic Engineering, 2013.

[26] FAO, aquastat, FAO's Information System on Water and Agriculture, 2013. http://www.fao.org/nr/water/aquastat/main/index.stm 